\title{
ENJOYING THE NFL IN BRAZIL THROUGH SOCIAL TV
}

FRUINDO A NFL NO BRASIL POR TV SOCIAL

Recebido em 29.07.2019 Aprovado em 25.11.2019

Avaliado pelo sistema double blind review DOI: https://doi.org/10.12712/rpca.v13i4.29511

\section{Bruno Melo Moura}

brunomtop@gmail.com

Programa de Pós-Graduação em Administração da Universidade Federal de Pernambuco (Propad / UFPE), Recife - PE, Brasil. https://orcid.org/0000-0002-8205-4576

\section{André Luiz Maranhão de Souza-Leão}

desouzaleao.pq@gmail.com

Programa de Pós-Graduação em Administração da Universidade Federal de Pernambuco (Propad / UFPE), Recife - PE, Brasil.

https://orcid.org/0000-0002-7660-5845

\begin{abstract}
NFL Brazilian broadcasts is distinguished by the interaction of fans through social media. By reverberating television content in another media, they establish the phenomenon of Social TV. The research pursues to respond how Brazilian viewers enjoy the NFL through Social TV. For this purpose, we performed a netnography based on three league seasons, through 2016 to 2019. Results reveal Brazilian viewers enjoy the NFL through Social TV because it propitiates them to participate in the broadcasting, what becomes more important than the games itself. Based on this, we argue that NFL fans and ESPN channels co-prosume a simulation turned possible due to the current mediatized world.
\end{abstract}

Keywords: NFL. Social TV. Fans. Prosumption. Netnography.

\section{Resumo}

As transmissões brasileiras da NFL se distinguem pela interação de fãs em mídias sociais. Ao reverberar o conteúdo televisivo em outra mídia, estabelecem o fenômeno da TV social. A pesquisa busca responder como espectadores brasileiros fruem a NFL por meio da TV Social. Para tanto, realizamos uma netnografia baseada em três temporadas da liga, entre 2016 e 2019. Os resultados revelam que espectadores brasileiros fruem a NFL por meio da TV Social por ela propiciar que participem das transmissões, o que se torna mais importante do que os próprios jogos. Com base nisto, argumentamos que os fãs da NFL e os canais ESPN co-prossumem uma simulação tornada possível graças ao atual mundo midiatizado.

Palavras-chave: NFL. TV Social. Fãs. Prossumo. Netnografia. 


\section{Introduction}

The entertainment capacity of the sports has provided them a constant growth of interest. Given technological advances of communication, they become globalized in that they are broadcasted in different media worldwide. However, it also makes them serve as tools for the dissemination of cultures that were once restricted by physical and geographical limitations (Jackson, 2014; Toffoletti, 2015). Precisely because they incorporate aspects of the culture to which they are part, sports exceed their entertainment characteristic, for they also transform it, in a mutual, dynamic and continuous relationship (Davis, Fodor, Pfahl \& Stoner, 2014, Keaton \& Gearhart, 2014); therefore, the way that sports consumers react to their content has been changed how they are diffused. Between this and that, sports are an excellent tool for the understanding of modern societies (Serazion, 2012; Wenner, 2012; Whannel, 2014).

As a form of entertainment, sports can be classified into two categories, according to Whannels (2014): media sports, tied to the wide space they hold in the broadcasts and the consequent involvement reached with their audience; and participation sports, which have popularity thanks to the large number of practitioners in the society in which they are inserted. The relationship between them is dynamic, since media sports can stablish thanks to the popularity of its practice, as well as participation sports may derive from the success of their broadcast.

Over the years and the evolution of technologies available on the Web, media sports and its broadcast have been adapted to meet new demands of their audience (Turner, 2007, 2012). Many of them have become global phenomena due to their worldwide broadcast. However, some of them, even though becoming popular around the world, may not be considered global, if their practice and rules cause estrangement in local cultures (Wenner, 2012; Whannel, 2014). It is the case of the American football, the most popular U.S.A. sport. Despite its widespread in several other countries as a media sport, it has not become a participation sport in most of these locations, making it cannot be considered global yet.

American football emerged as a merge of two types of English-made football: football association and football rugby. From the popularization of its practice, the sport was adapting and differentiating from those that gave it origin. In this long road, the sport became strongly related to its main championship, the National Football League (NFL), that was responsible for disseminating, popularizing and making it the most popular American sport since the 1960s (Mancha, 2015; Paolantino, 2008). Widely mediated by the entertainment industry, the enhancement of both the sport and the league has been targeted primarily to those who enjoy the NFL through its games broadcast (Wenner, 2008). Herewith, NFL became a mainstream sport league worldly and the Super Bowl, the final game of the season, turned into one of the biggest global mega-events of entertainment (Spotts, Purvis \& Patnaik, 2014, Wenner, 2014). Annually, it breaks record of hearing not only in the U.S.A., as in several other countries (BBC, 2015, Capital Mexico, 2017, TSN, 2016).

Brazil is currently the NFL's second major consumer market outside U.S.A., with almost 20 million viewers. It is behind only Mexico, home to at least one league game per year since 2016 (ESPN Brasil, 2015; Francischini, 2018). In 2018, the Super Bowl LII hit a record audience in the country for the third year in a row: ESPN Brazil had a 14\% growth over the previous year (Firmino, 2018; UOL Esportes, 2018). Such growth is stimulated by the ESPN's Brazilian channels through campaigns that encourage the interaction of their audience in social networks (Magri, 2018). How the country is one of the largest consumer markets for social media (Yokoyama \& Sekiguchi, 2014), was natural to local ESPN launches Twitter hashtags for viewers to comment the games and other issues of the league. During the broadcasting breaks, ESPN Brazil's staff show and comment messages, as well as answer questions about the game (Firmino, 2018; Mesquita, 2017). This indicates how NFL is growing into an emblematic entertainment for their audience in Brazil.

The entertainment capacity of media products, specifically television programs, establishes an intimate relationship between brands and their audience (Draganska, Hartmann \& Stanglein, 2014). Increasingly, 
viewers identify with TV content, no longer behaving as passive receivers (Batra \& Keller, 2016). Once media sports content production (i.e., broadcast) is simultaneous to its consumption, it may induce synchronized cooperation with and among its consumers (Dias \& Rossi, 2017). When consumers engage and seek to appropriate of content, they take on themselves functions that originally belong to producers, acting as prosumers (Ritzer \& Jurgenson, 2010, Collins, 2010). One of the most regular practices of prosumers is to aid in the redistribution of the content they consume (Ritzer, Dean \& Jurgenson, 2012; Ritzer, 2014), with social media being the medium they use most to do so (Deller, 2011; Nunomura, 2013).

We follow the assumption of Leão and Costa (2018) that prosumption is a fan activity par excellence. They do it by taking part in a participatory culture, by appropriating the available technology and democratically reinventing the way they communicate from mediatic texts (Chen, 2018). They are no longer limited to react to media content, being able to archive, appropriate and reproduce it in innovative ways (Jenkins, Ford \& Green, 2013), mainly through social media (Jenkins, 2006; Langlois, 2013).

When viewers choose to reverberate TV content through social media, they plot the phenomenon called as Social TV. It refers to the act of the audience not to be restricted to the reception of television content and to use a second screen (computer, smartphone, tablet or any technological gadget that allow access to the Internet) to access a social media and talk about what they are watching (Proulx \& Shepatin, 2012). Thereby, viewers reinvent the enjoyment of watching TV by engaging in interactions via social media (Cruz, 2015; Kramer, Winter, Benninghoff \& Gallus, 2015). Such engagement reveals not a consumption exchange from television to social media, but a multiplication of TV shows content through the accessibility afforded by Web 2.0. (Finger and Souza, 2012). By means of this, Social TV allows to understand the sense of community that is established among the consumers of a media product (Kramer et al., 2015, Pagani \& Mirabello, 2011).

So, it is possible to say that the interaction of the NFL's Brazilian audience on Tweeter transforms the enjoyment of the games broadcast in a singular experience of participatory TV watching. Based on this, the research pursues to respond how Brazilian viewers enjoy the NFL through Social TV.

The study shows relevance due to the importance of identifying the aspects that are capable of modifying the reception and consumption of television content, as an emblematic media product. There are works that demonstrate the strength that social media have for the buildup of a brand or consumer culture, such as Parmentier and Fischer (2015) on the repercussion of the American Next Top Model, and Armstrong, Delia and Giardina (2014) on and the formation of a National Hockey League (NHL) team. Nevertheless, those works do not show the impact of social media on worldwide television content, as well as the importance of local broadcasting in making viewers become fans. In this sense, the research presents how the phenomenon of Social TV can contribute to marketing studies as a valuable theoretical interdisciplinary construct, especially in investigations of objects linked to two of the most popular forms of entertainment today: television broadcasts and social media.

\section{Social Media as a Space for the Fan's Prosumption}

We live in a moment in which technological and organizational changes regarding work, productive relations and consumption led society to arrange into a network (Castells, 2003; Giglio, 2011). This plotted a dynamic social and economic connections, capable of promoting transformations in cultures that can now be better observed from virtual practices, configuring a cyberculture (Canclini, 2006; Lévy, 2007).

Cyberculture, according to Lévy (1999), is configured in a communication infrastructure that operates through devices capable of connecting people. It occurs via a network with a great amount of information which its users handle and feedback. Cyberculture impacts individuals and social practices in terms of 
interactivity and sociability, modifying established cultures (Morato, Arcoverde \& Leal, 2017, Noveli, 2010).

In this new social and cultural context, individuals look for information from diverse sources, keep permanently connected and interact virtually, in a contributive process called participatory culture (Jenkins, 2008; Tombleson \& Wolf, 2017). Cultural transformations cybernetically established are vital to the process of creating participatory cultures. It happens along with the media convergence and the technological appropriation, by an audience that resignifies, recreates, and make circulates reshaped media products (Guschwan, 2012; Jenkins, 2006).

Web 2.0 overtures several spaces that can be used as extensions of the consumer experience, what allows producers to develop and make available content to complement what they offer to the consumer markets (Chen, 2018; Denegri-Knott \& Molesworth, 2010). On the other hand, netizens may share interpretations of such content, what is done primarily through social media (Boulaire, Hervet \& Graf, 2010; Kozinets, 2001). Social media, thence, are emblematic for participatory culture, as it betokens how its users, by appropriating available digital technology, reconfigure the way they relate, with effect on content producers (Jenkins, 2006). This is because these platforms have established their popularity based on the ability of hosting content derived from the participation of their users. It renews the logic of communication, since it has as central practice their daily life (Jenkins, 2006, Langlois, 2013).

When used to share common interests, social media are structured as online communities. Once configured by consumers themselves, online communities become ideal social spaces for exchange of experiences, turning into a thermometer of consumer opinions and providing understanding of the audience of a certain media text (Deller, 2011; Nunomura, 2013). Kozinets (1999) points out that the participants of online cultures are its cornerstone, highlighting the members recognized among their peers - called insiders - for their leadership and spontaneous contribution to the community to which they are a part.

When consumers assume responsibility for coproducing their consumption experiences, a task that in the production-consumption dual model is a function of producers (Ritzer, 2014, Zajc, 2015), takes place the so called prosumption (Chen, 2018; Ritzer \& Jurgenson, 2010). This process becomes even more emblematic in the context of Web 2.0 technologies, that potentiate the role of prosumers and their participation in productivity of what they consume (Leão \& Costa, 2018; Ritzer \& Jurgenson, 2010).

Web 2.0 has allowed new possibilities for dialogues between members of the same culture that help in understanding the object that originally united them (Hartamann, 2015). More than that, the new possibilities of the digital platform led consumers to produce their own content that has particular meanings for the consumption of the original object, a practice known as User-Generated Content (UGC) (Andrew \& Ritzer, 2018; Ritzer, 2014). The main reasons behind this type of production are to influence and entertain other pairs, as well as sharing consumer experiences (Tapscott \& Williams, 2006), being social media the most suitable means for this practice (Collins, 2010; Ritzer, Dean \& Jurgenson, 2012).

In the context of media products, these prosumers are active and engaged fans (Leão \& Costa, 2018), who appropriate the media texts in order to express themselves (Guschwan, 2012). It is about a collective behavior that occurs in online communities known as fandoms, where fans can debate, consolidating a participatory culture through proactive and dynamic acts (Jenkins, 2008). Andrew and Ritzer (2018) highlights how such kind of engagement is capable of modifying the enjoyment of media sports. 


\section{Social TV: A Phenomenon of Participatory Culture}

As social media are one of the main means of expression in modern society (Yokoyama \& Sekiguchi, 2014), dialogues about television content permeated on these digital platforms. These interactions lead individuals to not limit to a passive reception of media content, participating in the meaning of it, setting up what Proulx and Sherpatin (2012) define as Social TV. It refers to the way television shows may engage the audience by connecting TV content to the web and social media. Thus, Social TV is the term representing the convergence between these two media.

Social TV is a communication process established by a two-screen phenomenon, when both TV and some device connected do the web are simultaneously linked to the same content. It creates a new kind of audience, based on the engagement on social media (Cruz, 2015, Kramer et al., 2015). Thus, Social TV has changed the way television content is enjoyed, leading viewers - especially fans - to take part in their own experience production (Kosterich \& Napoli, 2015, Proulx \& Sherpatin, 2012). Hence, in the Web 2.0 era, television have been adapted to meet new societal demands (Turner, 2007). Regarding specifically sports broadcasts, an identification between the audience and the content they consume has been pursued (Pegoraro, Ayer \& O'Reilly, 2010).

If initially the web was considered a competitor of television, today it is understood as a medium in which the audience may reverberates television content (Ducheneaut et al., 2008; Kramer et al., 2015). Since web and social media end up engaging viewers and even attracting new audiences, television content tends to be propagated more widely (Cruz, 2015; Proulx \& Sherpatin, 2012).

Thanks to a proactive and non-compulsory participation of the television audience in social networks, a new public is presented to television content that, originally, it did not know thanks to digital platforms (Malmelin \& Villi, 2016; Noguera Vivo et al., 2013). According to Finger and Souza (2012), television viewers' engagement through a different platform means a TV victory, since the repercussion of television content on a second screen has shown its strength and consolidated it as a medium capable to provide an experience more complex and interactive.

The use of web and social media for communicating is known as Computer-Mediated Communication $(\mathrm{CMC})$, in which individuals connect in network are able to interact with each other. In such a way, communication through technological devices works as equivalent to social encounters (Freitas \& Leão, 2012; Iqani \& Schroeder, 2015), characterizing CMC as a form of contemporary social relation (Jenkins, 2008; Kozinets, 2015). Kramer, Winter, Benninghoff and Gallus, (2015) consider that the Social TV phenomenon resumes the idea of consuming television contents together, a practice that was former common among family, but was lost over time. By communicating through Social TV, viewers develop a sense of belonging by communicating with people with similar interests.

Fans engaged in CMC assume the role of content spreaders (Jenkins, 2008), with technical and cultural potential that does not depend on the permission of its producers (Malmelin \& Villi, 2016; Noguera Vivo et al., 2013). For Jenkins, Ford and Green (2013) this is because spreadable media, by definition, is the cultural way audiences spontaneously share the content they receive. It is only possible because of the continued availability of content, its relevance to different audiences, and the portability that allows content to move between different platforms.

\section{Methodological procedures}

The research is an ethnographic study, since we look at a cultural community, seeking to observe how it works, as well as the interactions among its members (Geertz, 1989; Noveli, 2010). The study is part of an interpretative tradition of qualitative research (Lincoln, Lynham \& Guba, 2018). We used the literature both to base the research question of and to conduct the investigation and interpretation of the findings, 
without anticipating them, what characterizes the study as of inductive mainly character (Leão, Mello \& Vieira, 2009).

Once the observed community is established online, we conduct a virtual ethnographic study. Specifically, we adopt Netnography, an interdisciplinary method that allows the researcher to study online communities (Scaraboto \& Pereira, 2013; Kozinets, 2010) through virtual social behaviors (Bartl, Kannan \& Stockinger, 2016, Hamilton \& Alexander, 2017; Izogo \& Jayawardhena, 2018). Netnography is a specialized form of ethnography and uses computer-mediated communications (CMC) as a data source to understand a cultural phenomenon on the Internet (Freitas \& Leão, 2012; Noveli, 2010). The approach is tailored to study forums, newsgroups, blogs, social networks, etc. (Kozinets, 2010; 2015). Therefore, the method can captures the differences which are not sensitive to ethnographies developed for anthropological purposes conducted in physical loci (Hamilton \& Alexander, 2017; Scaraboto \& Pereira, 2013). Netnography is an evolution of the traditional ethnography, dealing with necessary adaptations in the way of investigating changes in the social life and relationships (Kozinets, 2015).

Due to its potential, Netnography has been the most widely used approach for the investigation of virtual consumer communities (Ferreira, Leão \& Paiva Júnior, 2014; Kozinets, 2010). The method focusses on investigating how Web users create and promote the maintenance of an online culture (Scaraboto, Vieira \& Costa, 2012), in a particular model of online observation (Colliander \& Hauge Wien, 2013; Kozinets, 2010; Underberg \& Zorn, 2013). We employed the approach proposed by Kozinets (2001, 2010, 2015), developed for the purpose of conducting consumer research and that has been used to observe sport media viewers (Filo et al., 2015; Næss, 2017; Stavros et al., 2014).

Kozinets (2001, 2010, 2015) establishes three fundamental steps for the accomplishment of a netnography. We present below these steps and the way we conduct them in the present research.

\section{Cultural Entrée}

Communities representing the phenomenon to be investigated must be accessed in order to map their social interaction functioning. Two things are fundamental to the cultural entrée: the recognition of the field and how it works, and, mainly, the way how the researcher will be naturalized to the group. Kozinets (2010) explain this step as the familiarization of the researcher with the cultural context to be observed, after choosing the virtual community representative of the phenomenon that will be studied.

For our investigation, we chose the largest community of Brazilian NFL fans: the audience of ESPN channels that interacts on Twitter about the league news and broadcast. The Brazilian ESPN was the first Pay TV channel to broadcast NFL games - since September 1992 - and since 2017 holds exclusive rights for broadcasting the league in the country (Firmino, 2018; Francischini, 2018). In our study, the community investigated was formed amid the hashtags \#TudoPelaNFL, \#PlayOffsNaESPN, \#SuperBowlNaESPN and \#NFLnaESPN. They were launched by ESPN channels in Brazil on the social media Twitter to promote the interaction of its viewers among each other and with the channel during the broadcasts of NFL games for the 2016-17 (first three hashtags), 2017-18 and 2018-19 (last hashtag) seasons. In terms of familiarity, researchers have followed league games since 2009, with one of them, responsible for data collection, interacting on ESPN Brazil hashtags 7 years ago. In addition, the latter has also been practicing American football on a Brazilian team since 2012, having played national championships of the sport in every year since then.

\section{Data collection}

Refers both to the register of the texts published by the participants of the online community investigated, and to the field notes of the researchers, since the context in which the data is produced and posted is often crucial to understand the production conditions of such texts. Such a process can be done in more than one round, since during the analysis and interpretation new data can be collected to complement 
this process. As Kozinets (2010; 2015) explain, the netnography data collection starts with archiving the CMCs that can be obtained from interactions between blog users, online communities, or forums. In addition to texts, photographs, artwork and sound files may be considered. If necessary, the researcher may contact the participants of the investigated community, in order to obtain complementary data.

We collected all messages posted on Twitter hashtags regarding NFL broadcasts in Brazil by ESPN in 2016-17, 2017-18 and 2018-19 seasons. The periods of collecting data followed each season, that happens from the first week from September to the first Sunday of February. It covered all the 300 games broadcasted, being 119 on the 2016-17 season, 141 on the 2017-18 and 138 on 2018-19. Following the first season observed we performed complete data analysis. During the second and third period of observation we focused on data saturation, not losing sight of potential new findings.

\section{Data analysis}

The analysis and interpretation of the data is an analytical process composed of procedures divided into six stages:

- Coding refers to the hierarchical classification of the first impression analyzed in the collected data;

- During the coding, field notes are elaborated based on reflections that arise from the analysis;

- Abstraction and comparison are required for classifying codes and filtering those on the same subject;

- For verification and refinement purposes, it is necessary a return to the online community, seeking to isolate and saturate the understanding of the patterns perceived in the previous stages;

- Generalization are the elaboration of a set of general meanings that encompass and explain the consistency of what has been observed;

- Theorization is a confrontation of the results with theories that adhere to the investigated phenomenon.

We organize these procedures in three stages of analysis: elaboration of provisional codes and establishment of relationships and hierarchies between them; refinement of the identified codes and classification of them into categories resulting from their relationships and hierarchies; use of existing literature to interpret findings, with elaboration of nomenclatures and definitions for the codes and categories. Thus, the analysis had an inductive phase, when we analyzed the data of the first season, adopting general notions as initial basis and more specific concepts to validate the inferences; and a deductive phase, when analyzing the data of the second season from the findings of the previous one, although keeping the process open to the identification of new codes and categories.

\section{$\underline{\text { Netnography criteria }}$}

Such procedures evidences how we followed the criteria of quality of a netnography according to Kozinets (2015): search for data saturation; theorization in the interpretation of the findings; rigor on the method application; axiological demarcation in the cultural context of the research; reflexivity on data analysis; and respect for the observed praxis. In addition, we performed a triangulation of the analysis among the researchers and sought to present the results by means of a clear, rich and detailed description (hereafter) (Paiva Júnior, Leão \& Mello, 2011). 


\section{Results}

Our analysis came to the identification of eight codes, organized into two categories. They are described and discussed below, illustrated with stretches of data extracted from the research corpus. In Figure 1 we illustrate the results, presenting the relations between codes, categories and the major finding of our analysis.

Figure 1 - Codes, Categories and Major Finding

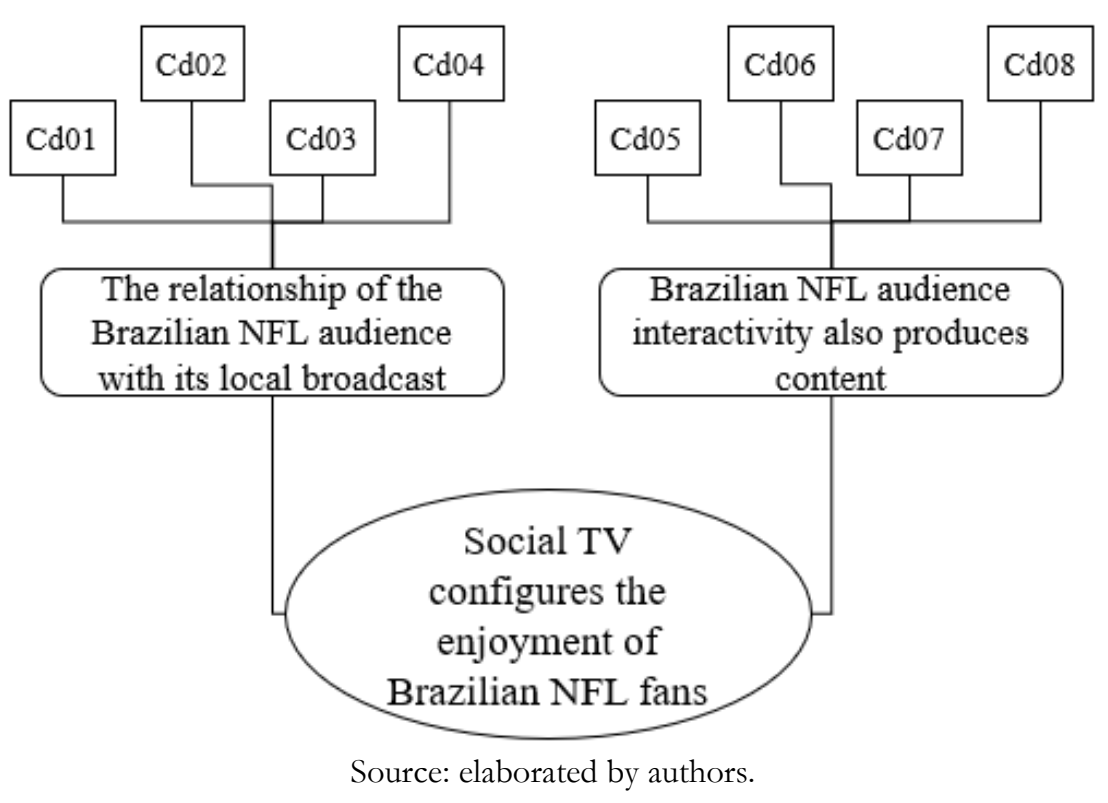

The relationship of the Brazilian NFL audience with its local broadcast

The NFL's Brazilian viewers use Twitter to dialogue interactively among them, as well as with the Brazilian ESPN broadcast staff. The relationship between the audience and the television channel team can alter the games enjoyment. It because the Brazilian ESPN use social media as a means of interaction with its viewers and go after their involvement with the transmitted media text. Thus, this category points out how the Brazilian audience relates to the local channels of ESPN from the way the NFL is broadcasted in the country.

A first code of the category reveals how the fans realize the narration and comments of Brazilian ESPN on NFL broadcasts as incredible (Cd01). Due to its exalted emotion, the audience considers it with no close comparison, either considering other sports broadcasts or the league games in other countries. The way of conducting the broadcast is so passionate that viewers seek to watch the games with the ESPN audio, through ESPN website and streaming, even when traveling. In tweets posted on \#TudoPelaNFL we highlight excerpts such "the best narration, considering all sports" and "nothing compares to the emotion of narration on our ESPN". This perception can also be observed when the NFL itself resolves to highlight the Brazilian narrations in their official websites. One of the most emblematic cases was Everaldo Marques' narration of an extremely unusual move in the sport - known as "Hail Mary" - that occurred in the early hours of January 8, 2017, in the match between Green Bay Packers and New York Giants. The way of narrating the special play was so exalted by the league's Brazilian fans in social medias, that the Packers website called it "quite possibly the most exciting Hail Mary call yet!".

The next code indicates how Brazilian fans think ESPN local team make NFL broadcasts more fun (Cd02). ESPN Brazil narrators and commentators uses to approach themes not directly related to 
American football or the NFL itself. They make comments about a variety of matters, such as the Brazilian politics news; the translation of American films titles for the country release; pop culture products, such as film, TV series, comics and music artists; and curious Brazilian terms or jargons. To illustrate this, we highlight a situation occurred on the transmission of a match in October 2, 2016. The commentator Antony Curti announced the return of Pokemon and Dragon Ball Z, two Japanese animated series very famous in Brazil during the 1990s, in a public channel TV. The narrator Ary Aguiar did not know differentiating them, what made viewers animatedly reverberate this knowing less.

The third code concerns the Brazilian fans involvement with terms whose use has a particular meaning created by the ESPN team members (Cd03). Each narrator or commentator has humor expressions that has fallen in the taste of the league fans, but that are not understood outside the context of the broadcasts. The empathy created is so huge that ESPN released the most famous expressions of its team to download on the official website and application for smartphones. These terms are so inherent do the relation between fans and ESPN staff that sporadic audience does not understand them. At the end of the halftime show of the Super Bowl LI, the narrator Everaldo Marques said "Lady Gaga, you are ridiculous!". The repercussion was unprecedented, so much that the narrator's name and the term "ridiculous" came to a head in world Trending Topics of Twitter. It because some viewers tuned the channel only to watch the singer's show. Not accustomed with the term use in the American sense, since in Brazil it is offensive, these viewers thought the narrator was belittling the artist. The fans made a point of explaining on the tweets that the narrator was indeed praising Lady Gaga, since he often uses the term to extol extraordinary performances in the matches.

In an unfolding of previous codes, the Brazilian NFL viewers becomes fans of the ESPN local team (Cd04). For them, Brazilian ESPN narrators and commentators integrate and qualify the NFL product package. The social media audience builds a heartfelt, esteemed and exhilarating connection with the ESPN staff, mainly because of the good humored and interactive broadcasts. A tweet posted on November 7, 2016, exemplifies this feeling well, when a viewer highlights not only to be a fan of ESPN broadcast team, but also to consider it the best he has ever seen in sports broadcasting at all and that without this NFL games would not that positive.

\section{Brazilian NFL audience interactivity also produces content}

The other category reveals how Brazilian NFL fans do not restrict to the passive reception of the content they consume in the league broadcasts in the country. Although the communication between members of the audience is proposed by ESPN, the way the fans behave in their relationship acquires own contours. It is a warm relation, seen usually only among sports fans who use to consume in loco. More than that, it is stablished a tie that leads some of them to feel responsible for helping their peers' consumer experience by producing particular content.

In this vein, one of the identified codes reports that some Brazilian Twitter profiles took on the task of spreading NFL content (Cd05). Because there is a limitation on the number of games transmitted by Brazilian ESPN, due to a restriction of contract with the NFL, the broadcaster cannot transmit or make available all the games in the league. So, some fans use the social media to inform about the games not broadcasted, mainly in updating the scores of these matches.

In other direction, the fans also use the Twitter to demand deeply information on the game and its rules. On 2016 September 22, Everaldo Marques took some time answering a question posted by a viewer questioning the existence of rules created from emblematic situations in past seasons of NFL.

In another front, some fans create specialized profiles about NFL, pursuing to spread the league in Brazil. They do this with no pecuniary gain but rejoice when are mentioned on the ESPN broadcasts. Among the profiles, Luluzinha Club stands out for being created and managed only by women and, in the 2017- 
18 season, celebrated the hiring of Paula Ivoglo, one of the managers of the profile, as an ESPN commentator for the NFL.

The following code reveals that Brazilian NFL audience produces memes that makes broadcasting more fun for those who access hashtags (Cd06). The memes make the experience of "reading" media texts more humored. It has turned the virtual interaction as interesting as watching the league itself, according to reports in tweets throughout the NFL season. Among the best known, there may be the drinking game - a game created by fans that brings together scores of ESPN Brazil storytellers and commentators, and who get the fan to turn a dose of alcohol whenever they are enunciated during games - which is even quoted several times by the teams broadcasting the games as a way to make the NFL more lively.

The third code of this category presents the adoption of cinema broadcast by part of the Brazilian NFL audience, as a form of experiencing an innovative way of watching the Super Bowl (Cd07). The final game of the season was broadcasted in cinemas of many cities in Brazil - since Super Bowl XLVIII in February 2014 -, including the 3D option. Several fans uploaded, on Twitter, pictures of the tickets or movie theaters with friends, as well of themselves anxiously waiting for the most important game of the season.

Finally, the latest code points how Brazilian NFL broadcasts encouraged their fans to watch league games in loco (Cd08). Some of NFL fans in Brazil attest that because of the league broadcasts on local ESPN channels, they decided to get to experience the game directly at the source. Many are the tweets of Brazilian fans that traveled to the U.S.A. stadiums to watch an on-site match keeping the moment through photos published on the hashtags and seeking to remain connected with the Brazilian transmission that impelled them to be there.

\section{Discussion}

Our findings align with the understanding that content and consumption in the sports entertainment industry are simultaneously produced, in a synchronized cooperation between producers and viewers of television broadcasts (Dias \& Rossi, 2017). Besides, in the digital age the conducting of content presentation to the audience has been significantly changed (Turner, 2007; Thompson et al., 2015), turning social media one a main way of interaction between viewers, what potentializes their participation on broadcasting (Ducheneaut et al., 2008).

The first category reveals how Brazilian NFL fans consider important the ESPN's broadcast for NFL consumption. Along the game broadcasts in the country, they exalt the quality of the ESPN Brazil team. The personal charisma and the Brazilian way of conducting the sports broadcast leads the local NFL fans to establish a direct relationship with the channel. The Brazilian ESPN style of broadcasting the NFL games is so appreciated by the local fans, that they demonstrate to take part of a community lined off by codes and values.

On the other hand, the second category acknowledges the engagement of the Brazilian NFL audience in improving the league games' enjoyment. It happens both by the production of content and the sharing of experiences in watching the games. These actions demonstrate how Brazilian NFL fans compromises in the qualification of the game broadcasts, as with the spreading and strengthening of the league.

The findings corroborate the understanding that the experience of interacting in virtual communities happens through its user's production of content and the bonds they nourish with what they enjoy (Kozinets 1999, 2001), modeling the enjoyment of a collective consumption (Parmentier \& Fischer, 2015). In line with this, Thompson et al. (2015) points how television on digital age needs a mediaenhanced audience. Through a combination of self-promotion and production assistance, consumers become able to accumulate expertise which can make a TV show a phenomenon in social media. 
The active participation of Brazilian NFL fans on the ESPN broadcasts reveals social practices that cannot be observed in physical social relationships, running only in online communities, as pointed by Kozinets (2001). This proactive and non-compulsory prosumer participation turns the Brazilian fans into NFL spreaders on social media (Malmelin \& Villi, 2016; Noguera Vivo et al., 2013).

Web 2.0 technologies have modified the way the sports audiences receive TV content (Turner, 2007, 2012; Thompson et al., 2015), what, in turn, induce changes in the sports broadcasts. In a participatory culture context, Brazilian NFL fans complement the understanding of the media product that unites them, influencing the culture in which they are embedded (Jenkins, 2008), and acting as Web 2.0 prosumers (Hartmann, 2015; Ritzer, 2014). These are the ties that Jenkins (2006) points out as inherent to participants in a fandom, what strengthens the fans relationship and their link to the media product they admire.

The productive capacity of the audience to influence broadcasts reveals not only its role as a prosumer (Collins, 2010), but how media companies considers it a major role in their engagement (Thompson et al., 2015). That's why producers recognize the role of consumers in the production system, by stimulating their participation on product and brand associated-meaning production (Ritzer, 2014).

The continuous interactions among Web 2.0 based fans arranges a collective intelligence (Jenkins, 2008). Considering the importance that the cyberculture has in the way of communicating nowadays, interactions through CMC have repercussions that go beyond the virtual environment (Iqani \& Schroeder, 2015; Lévy, 2007). They can be considered as evidence of a growing mediatization of social life. This phenomenon concerns how social processes have been reconfigured by the intensive use of media, which become increasingly ubiquitous and thus intertwined with the social fabric. Thus, the social reality itself becomes increasingly constituted by communicational exchanges, which put people in a state of permanent visibility, culminating in processes of mutual control (Franco; Leão, 2016).

In line with this conception, CCT authors argument that the postmodern society is a simulacrum spread by the media in participative interactions (Chen, 2018; Denegri-Knott \& Molesworth, 2010; Rose \& Wood, 2005) and that this participative interaction between consumers, producers and different types of media represent a continuous enhance of emotional bonds within the consumption process, associated with the production and exchange of signs (i.e., symbols, meanings) as means for generating value (Bonsu, Darmody \& Parmentier, 2010; Thompson et al., 2015).

This understanding is based on Baudrillard (1991; 1999), that assumes the virtual as an imagined reality that has its own reality. Such reality is primarily mediated by representational signs and become a more real reality then the reality itself, since it is produced and experienced as a real instance that participants agree do share.

\section{Final considerations}

Our research has identified that the phenomenon of Social TV configures the enjoyment of Brazilian NFL fans by propitiating them to participate in its game broadcasts. This is made possible due to social media interactions, either through the relation established with the ESPN Brazil broadcast team, or through the online relationship stablished among the fans.

Present study demonstrate how NFL consumption in Brazil is closely related to the TV channel that broadcast the games. Even with the league's exclusivity from 2017, NFL fans kept extolling the quality of Brazilian ESPN broadcast.

Our study reinforces the importance of social networks in synchronous television broadcast. Increasingly, television channels that broadcast content of worldwide repercussions (e.g., major sports leagues and internationally released shows) need to integrate the social networks with such content. Using digital 
platforms synchronously to broadcast allows them to retain their viewers and, eventually, turning them into fans of the channels themselves. This occurs because the engagement in social networks leads them to spread the content of television channels through Social TV.

The study introduces the relevance of Social TV concept to marketing studies, especially Consumer Culture Theory research. Through Social TV phenomenon, this research explores how a media product, more specifically a media sports, has its television broadcasting modified thanks to its consumers interactive participation through social media.

Based on our interpretation of the findings, we argue that when fans interact about the NFL, they realize how much attractive it can be, becoming even more important than the NFL games themselves. The replacement of the real thing by the virtual experience of Social TV in online communities evidences a simulation co-prosumed by the Brazilian NFL fans and the ESPN channels. Such process, in turn, is made possible due to the appropriation and intensive use of communication technologies that permeates mediatized world.

The study focused only on the Brazilian NFL fans which participate of the league broadcasts through the ESPN hashtags on Twitter. Future research could extend this scope to spaces not mediated by the broadcaster. Thinking forward, we fathom that studies on similar topics to present research would benefit from this perspective. TV has increasingly expanded its the range of shows, as well as innovating the ways of accessing its content (e.g., streaming, DVR). Fans, in turn, have shown growing interest in multiplatform content.

\section{Acknowledgements}

National Council for Scientific and Technological Development (CNPq) supported the research.

\section{References}

Andrews, D. L., Ritzer, G. (2018). Sport and prosumption. Journal of Consumer Culture, 18(2), 356-373.

Armstrong, C. G., Delia, E. B., Giardina, M. D. (2014). Embracing the Social in Social Media: An Analysis of the Social Media Marketing Strategies of the Los Angeles Kings. Communication \& Sport, 4(2), 145165.

Bartl, M., Kannan, V. K., Stockinger, H. (2016). A Review and Analysis of Literature on Netnography Research. International Journal of Technology Marketing, 11(2), 165-196.

Batra, R., Keller, K. L. (2016). Integrating Marketing Communications: New Findings, New Lessons, and New Ideas. Journal of Marketing, 80(6), 122-145.

Baudrillard, J. (1991). Simulacros e simulação. Lisboa: Relógio d’ Água.

Baudrillard, J. (1999). Tela total: mito-ironias da era do virtual e da imagem. Porto Alegre: Sulina.

BBC (2015, February). Super Bowl attracts record 114.4m viewers on NBC [BBC.com] Retrieved from https://www.bbc.com/news/entertainment-arts-31108406.

Boulaire, C., Hervet, G., Graf, R. (2010). Creativity chains and playing in the crossfire on the videosharing site YouTube. Journal of Research in Interactive Marketing, 4(2), 111-141.

Bonsu, S., Darmody, A., Parmentier, M. (2010). Arrested emotions in reality television. Consumption, Markets and Culture, 13(1), 91-107.

Canclini, N. G. (2006). Estratégias para entrar e sair da modernidade. São Paulo: EDUSP.

Capital Mexico (2017, February). Super Bowl LI, lejos del récord de audiencia: Lady Gaga superó los 113.3 millones de televidentes que tuvo el Patriotas-Atlanta, [capitamexico.mx] Retrieved from http://www.capitalmexico.com.mx/estadio/super-bowl-li-lejos-del-record-de-audiencia.

Castells, M. (2003). A galáxia da Internet. Rio de Janeiro: Jorge Zahar.

Chen, Z. T. (2018), "Poetic prosumption of animation, comic, game and novel in a post-socialist China: A case of a popular video-sharing social media Bilibili as heterotopia". Journal of Consumer Culture, article first published online: July 12, 2018. 
Colliander, J., Hauge Wien, A. (2013). Trash talk rebuffed: consumers' defense of companies criticized in online communities. European Journal of Marketing, 47(10), 1733-1757.

Collins, S. (2010). Digital fair prosumption and the fair use defense. Journal of Consumer Culture, 10(1), $37-$ 55.

Cruz, B. P. A. (2015). Classe C e o fenômeno SOCIAL TV no Brasil. RAD - Revista Administração em Diálogo, 17(3), 106-128.

Davis, J. L., Fodor, A.; Pfahl, M. E., Stoner, J. (2014). Team interdependence and turnover: evidence from the NFL. American Journal of Business, 29(3-4), 276-292.

Deller, R. (2011). Twittering on: Audience research and participation using Twitter. Journal of Audience \& Reception Studies, 8(1), 216-245.

Denegri-Knott, J., Molesworth, M. (2010). Concepts and practices of digital virtual consumption. Consumption Markets \& Culture, 13(2), 109-132.

Dias, I. R. R., Rossi, G. B. (2017). How far is World Champion from World Class? Institutional effects on a Brazilian non-profit sports organization. BBR, Braq: Bus. Rev, Special Issue, 24-44.

Draganska, M., Hartmann, W. R., Stanglein, G. (2014). Internet Versus Television Advertising: A BrandBuilding Comparison. Journal of Marketing Research, 51(5), 578-590.

Ducheneaut, N., Moore, R. J., Oehlberg, L., Thornton, J. D., Nickell E. (2008). Social TV: Designing for Distributed, Sociable Television Viewing. International Journal of Human-Computer Interaction, 24(2), 136-154.

ESPN Brasil (2015, February 04). Brasil é $2^{\circ}$ país com mais fãs de NFL fora dos EUA, diz pesquisa. [ESPN.com.br], Retrieved from http://espn.uol.com.br/noticia/481491 brasil-e-2-pais-com-maisfas-de-nfl-fora-dos-eua-diz-pesquisa.

Ferreira, B. R. T., Leão, A. L. M. S., Paiva Júnior, F. G., (2014). Identificação e Diferença na Construção de Identidades Culturais de Torcedores Rivais dos Três Grandes Clubes da Cidade do Recife: Entre a Defesa e o Ataque em Interações Sociais Virtuais. Podium: Sport, Leisure and Tourism Review, 3(2), 8596.

Filo, K., Lock, D., Karg, A. (2015). Sport and social media research: A review. Sport Management Review, 18(2), 166-181.

Finger, C., Souza, F. (2012). Uma nova forma de ver TV no sofá ou em qualquer lugar. Revista Famecos, Porto Alegre, 19(2) 373-389.

Firmino, A. (2018, February 02). Conheça a bistória das transmissões do Super Bowl no Brasil. [A Tribuna]. Retrieved from https://www.atribuna.com.br/2.713/conheça-a-história-das-transmissões-dosuper-bowl-no-brasil-1.43517.

Francischini, G. (2018, September, 05). Detentora dos direitos da NFL no Brasil, ESPN transmitirá mais de 140 partidas em nova temporada da Liga [ESPN Press Room]. Retrieved from https://espnpressroom.com/brazil/press-releases/2018/09/detentora-dos-direitos-da-nfl-nobrasil-espn-transmitira-mais-de-140-partidas-em-nova-temporada-da-liga/.

Franco, S. M., Leão, A. L. M. S. (2016). Midiatização: da disciplina ao controle, um horizonte de reflexão. Revista Fronteiras - Estudos Midiáticos, 18(3), 289-304.

Freitas, G. K. A., Leão, A. L. M. S. (2012). A elaboração da face em comunidades virtuais de marca: um estudo de caso sobre uma comunidade virtual de consumidores da Coca-cola. Cad. EBAPE.BR, 10(1), 181-201.

Geertz, C. (1989). A interpretação das culturas. Rio de Janeiro: LTC Editora.

Giglio, E. M. (2011). Proposta e sustentação de um modelo de rede que inclui o ator consumidor. BBR, Braz. Bus. Rev, 8(1), 28-50.

Guschwan, M. (2012). Fandom, brandom and the limits of participatory culture. Journal of Consumer Culture, 12(1), 19-40.

Hamilton, K., Alexander, M. (2017). Spatial, temporal and social dimensions of a "destination-inmotion." European Journal of Marketing, 51(11/12), 2101-2117.

Hartmann, B. J. (2015). Peeking behind the mask of the prosumer: Theorizing the organization of consumptive and productive practice moments. Marketing Theory, 16(1), 3-20. 
Iqani, M., Schroeder, J. E. (2015). \#selfie: digital self-portraits as commodity form and consumption practice. Consumption Markets \& Culture, 19(5), 405-415.

Izogo, E. E., Jayawardhena, C. (2018). Online shopping experience in an emerging e-retailing market. Journal of Research in Interactive Marketing, 12(2), 193-214.

Jackson, S. J. (2014). Assessing the sociology of sport: On media, advertising and commodification of culture. International Review for the Sociology of Sport, 50(4-5) 490-495.

Jenkins, H. (2006). Fans, Bloggers, and Gamers: Exploring Participatory Culture. New York: NYU Press.

Jenkins, H. (2008). Convergence culture: Where old and new media collide. New York: New York University Press.

Jenkins, H. (2014). Rethinking 'Rethinking Convergence/Culture'. Cultural Studies, 28(2) 267-297.

Jenkins, H., Ford, S., Green, J. (2013). Spreadable media: creating value and meaning in a networked culture. New York: NYU Press.

Keaton, S. A., Gearhart, C. C. (2014). Identity Formation, Identity Strength, and Self-Categorization as Predictor of Affective and Psychological Outcomes: A Model Reflecting Sport Team Fans' Responses to Highlights and Lowlights of a College Football Season. Communication \& Sport, 2(4), 363-385.

Kosterich, A., Napoli, P. M. (2015). Reconfiguring the Audience Commodity: The Institutionalization of Social TV Analytics as Market Information Regime. Television \& New Media, 17(3) 254-271.

Kozinets, R. V. (1999). E-tribalized marketing? the strategic implications of virtual communities of consumption. European Management Journal, 17(3), 252-264.

Kozinets, R. V. (2001). Utopian Enterprise: Articulating the Meanings of Star Trek 's Culture of Consumption. Journal of Consumer Research, 28(1), 67-88.

Kozinets, R.V. (2010). Netnography: Doing Ethnographic Research Online. London: Sage.

Kozinets, R.V. (2015). Netnography: Redefined. London: Sage. 2015.

Kramer, N. C., Winter, S., Benninghoff, B., Gallus, C. (2015). How "social" is Social TV? The influence of social motives and expected outcomes on the usage of Social TV applications. Computer in Human Behaviour, 51, 255-262.

Langlois, G. (2013). Participatory Culture and the New Governance of Communication: The Paradox of Participatory Media. Television \& New Media, 14(2), 91-105.

Leão, A., Costa, F. (2018). A vida organizada dos fãs de Harry Potter. Revista Organização \& Sociedade, 25(84), 122-154.

Lévy, P. (1999). Cibercultura. São Paulo: Editora 34.

Lévy, P. (2007). Inteligência coletiva: para uma antropologia do ciberespaço. São Paulo: Loyola.

Lincoln, Y. S., Lynham, S. A., \& Guba, E. G. (2018). Paradigmatic controversies contradictions and emerging confluences, revisited. In N. K. Denzin and Y. S. Lincoln (Eds.), The Sage handbook of qualitative research (5th ed.). Thousand Oaks, CA: Sage.

Magri, D. (2018, February 4). Muito além do Super Bowl: futebol americano cresce em audiência e praticantes no Brasil. [El País] from https://brasil.elpais.com/brasil/2018/02/01/deportes/1517507665 087170.html.

Malmelin, N., Villi, M. (2016). Co-creation of what? Modes of audience community collaboration in media work. Convergence: The International Journal of Research into New Media Technologies, 23(2), 182-196.

Mancha, P. (2015). TOUCHDOWN! 100 Histórias Divertidas, Curiosas e Inusitadas do Futebol Americano. (1. Ed.) Panda Books. São Paulo.

Mesquita, P. (2017, February 2). Everaldo Marquesprojeta mais um Super Bowl e se assusta com tamanbo da NFL no Brasil. $\quad$ [Torcedores.com] Retrieved from https://www.torcedores.com/noticias/2017/02/everaldo-marques-projeta-super-bowl-pela-tv-ese-assusta-com-tamanho-da-nfl-no-brasil.

Morato, R. S., Arcoverde, M. T. B., Leal, M. V. (2017). A Solidão na Cibercultura e o Discurso do Consumo Consciente: Um Estudo na Campanha "\#Usarbempegabem" da Vivo. REMark - Revista Brasileira de Marketing, 16(1), 55-67.

Næss, H. E. (2017). Authenticity matters: A digital ethnography of FIA World Rally Championship fan forums. Sport Management Review, 20(1), 105-113. 
Noguera Vivo, J. M., Villi, M., Nyiro, N., De Blasio, E., Bourdaa, M. (2013). "The role of the media industry when participation is a product”. In: N. Carpentier, K. Schroder, L. Hallett (Eds.). Transformations. Late modernity's shifting audience positions. New York: Routledge, pp. 172-19

Noveli, M. (2010). Do Off-line para o Online: a Netnografia como um Método de Pesquisa ou o que pode acontecer quando tentamos levar a Etnografia para a Internet? Organização em contexto, 6(12), 107-133.

Nunomura, E. (2013). A imprensa, o Twitter e as eleições de 2010 no Brasil. Intercom - RBCC, 36(1), 103126.

Ozanian, M. (2017, October 24). The Forbes Fab 40: The World's Most Valuable Sports Brands 2017. [Forbes] Retrieved from https://www.forbes.com/sites/mikeozanian/2017/10/24/the-forbes-fab-40-theworlds-most-valuable-sports-brands-2017/\#628ecc693b84.

Pagani, M., Mirabello, A. (2011). The Influence of Personal and Social-Interactive Engagement in Social TV Web Sites. International Journal of Electronic Commerce, 16(2), 41-68.

Paiva Júnior F. G., Leão, A. L. M. S. \& Mello, S. C. (2011). Validade e Confiabilidade na Pesquisa Qualitativa em Administração. Revista de Ciências da Administração, 13(31), 190-209.

Paolantino, S. (2008). How football explain America (1 Ed.), Chicago: Triumph Books.

Parmentier, M., Fischer, E. (2015). Things fall apart: The dynamics of brand audience dissipation. Journal of Consumer Research, 41(5), 1228-1251.

Pegoraro, A. L., Ayer, S. M., O'Reilly, N. J. (2010). Consumer Consumption and Advertising Through Sport. American Behavioral Scientist, 53(10), 1454-1475.

Proulx, M., Shepatin, S. (2012). Social TV: how marketers can reach and engage audiences by connecting television to the web, social media and mobile. New Jersey: John Wiley \& Sons.

Ritzer, G. (2014). Prosumption: Evolution, revolution, or eternal return of the same? Journal of Consumer Culture, 14(1), 3-25.

Ritzer, G. Dean, P., Jurgenson, N. (2012). The coming of age of the prosumer. American Bebavioral Scientist, 56(4), 379-398.

Ritzer, G., Jurgenson, N. (2010). Production, Consumption, Prosumption: The nature of capitalism in the age of the digital 'prosumer'. Journal of Consumer Culture, 10(1), 13-36

Rose, R. L., Wood, S. L. (2005). Paradox and the Consumption of Authenticity through Reality Television. Journal of Consumer Research, 32(2), 284-296.

Scaraboto, D., Pereira, S. J. N. (2013). Rhetorical strategies of consumer activists: reframing market offers to promote change. BAR - Brąilian Administration Review, 10(4), 389-414.

Scaraboto, D., Rossi, C. A. V., Costa, D. (2012). How consumers persuade each other: rhetorical strategies of interpersonal influence in online communities. BAR - Brazilian Administration Review, 9(3), 246-267.

Serazion, M. (2012). The Elementary Forms of Sport Fandom: A Durkheimian Exploration of Team, Myths, Kinship, and Totemic Rituals. Communication \& Sport, 1(4), 303-325.

Spotts, H. E., Purvis, S. C., Patnaik, S. (2014). How Digital Conversations Reinforce Super Bowl Advertising: The Power of Earned Media Drives Television Engagement. Journal of Advertising Research, 54(4), 454-468.

Stavros, C., Meng, M. D., Westberg, K., Farrelly, F. (2014). Understanding fan motivation for interacting on social media. Sport Management Review, 17(4), 455-469.

Tapscott, D., Williams, A. (2006). Wikinomics: How mass collaboration changes everything. New York, EUA: Penguin.

Thompson, A. et al. (2015). Puppets of necessity? Celebritisation in structured reality television. Journal of Marketing Management, 31(5-6), 478-501

Toffoletti, K. (2015). Advertising the 2015 Cricket World Cup: Representing Multicultural Female Sports Fans. Communication \& Sport, 5(2), 226-244.

Tombleson, B., Wolf, K. (2017). Rethinking the circuit of culture: How participatory culture has transformed cross-cultural communication. Public Relations Review, 43(1), 14-25. 
TSN (2016, February 09) Super Bowl 50 is second most-watched on record in Canada. [TSN.ca], Retrieved from http://www.tsn.ca/super-bowl-50-is-second-most-watched-on-record-in-canada-1.435665.

Turner, P. (2007). The Impact of Technology on the Supply of Sport Broadcasting. European Sport Management Quarterly, 7(4), 337-360

Turner, P. (2012). Regulation of professional sport in a changing broadcasting environment: Australian club and sport broadcaster perspectives. Sport Management Review, 15(1), 43-59.

Underberg, N. M., Zorn, E. (2013). Digital ethnography: anthropology, narrative, and new media. University of Texas Press, Austin, TX.

UOL Esportes (2018, February 06) Super Bowl leva ESPN a quebrar recordes no Brasil pelo terceiro ano seguido. [UOL.com.br] Retrieved from https://uolesportevetv.blogosfera.uol.com.br/2018/02/06/superbowl-leva-espn-a-quebrar-recordes-no-brasil-pelo-terceiro-ano-seguido/.

Wenner, L. (2008). Super-Cooled Sports Dirt: Moral Contagion and Super Bowl Commercials in the Shadows of Janet Jackson. Television \& New Media, 9(2), 131-154.

Wenner, L. (2012). Reflections on Communication and Sport: On Reading Sport and Narrative Ethics. Communication \& Sport, 1(1-2), 188-199.

Wenner, L. (2014). Connecting events to advertising: Narrative strategies and dirty logics in Super Bowl commercials In: K. Dashper, T. Fletcher, N. McCullogh (Eds). Sport Events, Society and Culture, Abingdon: Routledge.

Whannel, G. (2009). Between culture and economy: Understanding the politics of media sport. In: B. Carrington and I. McDonald (Eds) Marxism, Cultural Studies and Sport. London: Routledge, pp. 6887

Whannel, G. (2014). The paradoxical character of live television sport in the twenty-first century. Television \& New Media, 15, 769-776.

Yokoyama, M. H., Sekiguchi, T. (2014). A Utilização de Sites de Rede Social no Trabalho: um Estudo de Caso em Empresas Brasileiras. BBR, Bra\%: Bus. Rev, 11(2), 91-121.

Zajc, M. (2015). Social media, prosumption, and dispositives: New mechanisms of the construction of subjectivity. Journal of Consumer Culture, 15(1), 28-47. 